\title{
KARAKTERISTIK DAN GENESA PENGAYAAN UNSUR-UNSUR TANAH JARANG PADA BATUBARA LAPANGAN BATUBARA MUARA TIGA BESAR UTARA, TANJUNG ENIM, CEKUNGAN SUMATERA SELATAN
}

\section{CHARACTERISTICS AND GENESIS OF RARE EARTH ELEMENTS ENRICHMENT IN MUARA TIGA BESAR UTARA COAL FIELD, TANJUNG ENIM, SOUTH SUMATRA BASIN}

\author{
Ferian Anggara' ${ }^{1,2}$, Mutiara Cikasimi ${ }^{1}$, Basuki Rahmat ${ }^{3}$, Sigit Arso Wibisono ${ }^{3}$, \\ dan Rita Susilawati ${ }^{3}$ \\ ${ }^{1}$ Departemen Teknik Geologi Fakultas Teknik Universitas Gadjah Mada, \\ ${ }^{2}$ Pusat Kajian Sumberdaya Bumi Non-konvensional, \\ Fakultas Teknik Universitas Gadjah Mada \\ ${ }^{3}$ Pusat Sumber Daya Mineral, Batubara dan Panas Bumi \\ ferian@ugm.ac.id
}

\begin{abstract}
ABSTRAK
Batubara telah menjadi salah satu sumber alternatif unsur-unsur tanah jarang (UTJ) seiring dengan meningkatnya permintaan terhadap kebutuhan unsur-unsur tersebut. Kondisi geologis spesifik menyebabkan pengayaan konsentrasi UTJ pada batubara. Keterdapatan lapisan tipis material vulkanik (tonstein) pada Lapangan Batubara Muara Tiga Besar Utara, Formasi Muara Enim, Cekungan Sumatera Selatan menjadi salah satu indikasi terdapatnya pengayaan UTJ. Penelitian dilakukan menggunakan metode petrografi sayatan poles, analisis-analisis $X$-Ray Diffraction (XRD), proksimat, dan geokimia; Inductively Coupled Plasma-Mass/Atomic Emission Spectroscopy (ICP-MS/AES). Analisis geokimia menunjukkan pola distribusi UTJ didominasi oleh tipe UTJ Berat (Heavy Rare Earth Elements, HREE). Plot diagram nilai $\mathrm{C}_{\text {outl }}$ dan $\mathrm{REO}_{\text {ash }}$ menunjukkan prospek pengayaan UTJ termasuk ke dalam daerah prospek. Pola distribusi UTJ dan anomali redox sensitive dan redox non-sensitive menunjukkan tipe genetik pengayaan UTJ adalah tufaan. Pengayaan UTJ terjadi oleh proses pencucian alkaline tonstein yang terendapkan pada fase penggambutan dalam pembentukan batubara.
\end{abstract}

Kata kunci: Unsur-unsur Tanah Jarang, batubara, tonstein, Muara Tiga Besar Utara

\section{ABSTRACT}

Coal has become one of the alternative sources of rare earth elements (REE) along with the increasing demand for them. Specific geological conditions cause enrichment of Rare Earth Elements (REE) concentrations in coal. Thin layer of volcanic material (tonstein) found at the Muara Tiga Besar Utara Coal Field, Muara Enim Formation, South Sumatra Basin is indicated the existence of REE enrichment. The study used petrographic method for polished section, analyses of X-Ray Diffraction (XRD), proximate, and geochemical; Inductively Coupled Plasma-Mass / Atomic Emission Spectroscopy (ICP-MS / AES). Geochemical analysis shows that REE distribution patterns is dominated by heavy rare earth elements (HREE) type. $C_{\text {outl }}$ and $R E O_{a s h}$ diagram plots show prospects for the enrichment of REE included in the promising area. The distribution patterns of REE and redox sensitive and non-sensitive redox anomalies indicate the genetic type of REE enrichment is tuffaceous. REE enrichment occurs by leaching of alkaline tonstein which is deposited in the peat swamp within the coal formation.

Keywords: Rare Earth Elements, coal, tonstein, Muara Tiga Besar Utara 


\section{MAKALAH ILMIAH}

\section{PENDAHULUAN}

Unsur-unsur tanah jarang/UTJ (rare earth elements/REE) merupakan sekumpulan unsur golongan kimia lantanida dan itrium (yttrium) (Humphries, 2011). Keterdapatan UTJ secara konvensional ditemukan pada endapan UTJ-besi (iron-REE deposit), endapan karbonatit (carbonatite deposit), endapan lateritik (lateritic deposit), endapan letakan (placer deposit), batuan beku peralkalin, dan pada urat (Castor dan Hedrick, 2006). Selain itu, UTJ dapat ditemukan pada batubara. Batubara telah menjadi salah satu deposit alternatif UTJ dengan konsentrasi yang dapat lebih tinggi dari deposit konvensional (Dai dan Graham, 2017). Keterdapatan UTJ pada batubara menjadi penting dan dipertimbangkan seiring meningkatnya permintaan akan kebutuhan UTJ. Studi mengenai batubara sebagai sumber UTJ telah dilakukan oleh peneliti sebelumnya (Eskenazy, 1987; Dai dan Jiang, 2012; Seredin dan Dai, 2012; dan Anggara dan Amijaya, 2018). Menurut Seredin dan Dai
(2012) terdapat 4 tipe genetik proses pengayaan UTJ pada batubara, yakni 1) terrigeneous, 2) tuffaceous, 3) infiltrasi, dan 4) hidrotermal. Formasi Muara Enim merupakan formasi pembawa lapisan batubara pada Cekungan Sumatera Selatan. Formasi ini terbentuk pada Miosen Akhir-Pliosen Awal (Baumann, 1973 dalam Shell Minjbouw, 1978). Pembentukan Formasi Muara Enim dipengaruhi oleh aktivitas vulkanisme Tersier di Sumatera (Gambar 1). Detritus vulkanik terbawa dan terdeposisi saat terjadi proses pengendapan, detritus vulkanik diindikasikan dengan lapisan tonstein yang terendapkan pada lapisan batubara Mangus, yakni Lapisan Batubara A1, B1 dan B2, C, dan di antara A1 dan A2 (Pujobroto, 1997). Studi yang dilakukan akan membahas mengenai tipe, konsentrasi, dan proses pengayaan UTJ pada batubara lapangan batubara Muara Tiga Besar Utara menggunakan data lapangan dan analisis laboratorium dengan memperhatikan kondisi geologis pada lokasi penelitian.

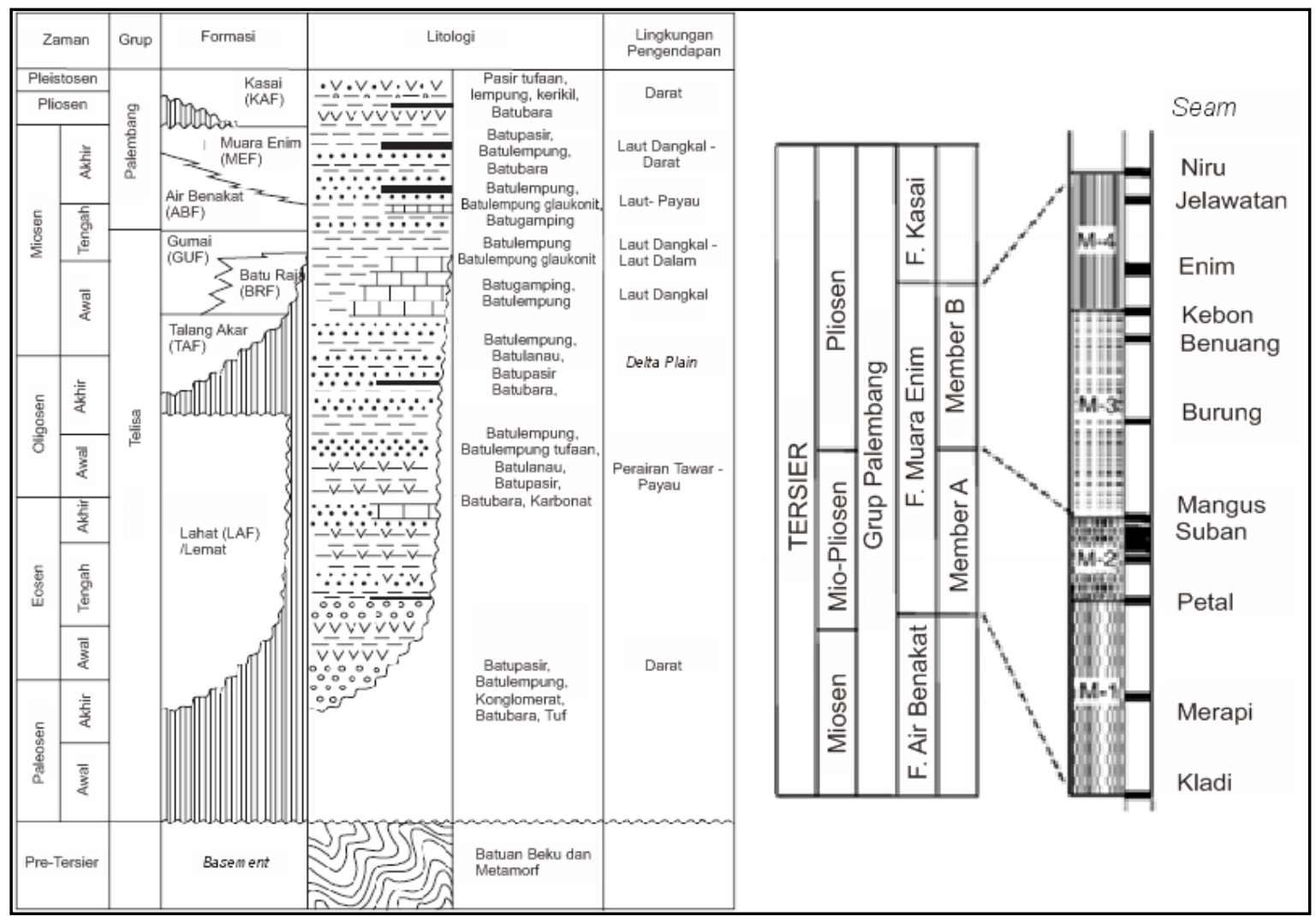

Gambar 1. Stratigrafi Cekungan Sumatera Selatan (Amijaya dan Littke, 2005), Anggota Formasi Muara Enim (Amijaya dan Littke, 2005) 


\section{METODOLOGI}

Penelitian difokuskan pada Lapisan Batubara Mangus, Formasi Muara Enim, Lapangan Batubara Muara Tiga Besar Utara (Gambar 2). Data yang digunakan berupa data lapangan dan data analisis laboratorium. Data lapangan berupa hasil pengamatan lapangan yang meliputi: deskripsi litologi, kolom stratigrafi rinci, dan conto batubara dan non-batubara. Sebanyak 14 conto batubara dan 6 conto non-batubara diambil pada satu jalur pengukuran. Pengambilan conto dilakukan pada batubara dengan ketebalan $20 \mathrm{~cm}$ dari parting dan pada batubara setelah batas $20 \mathrm{~cm}$ tersebut sebagai conto bulk. Conto non-batubara yang diambil merupakan lapisan parting (clay band) dan lapisan sedimen intraseam.

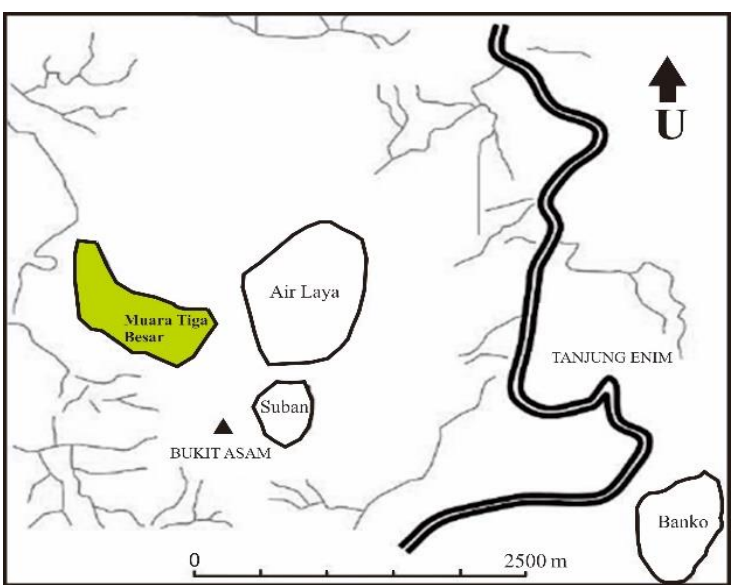

Gambar 2. Lokasi Penelitian (Susilawati dan Ward, 2006)

Analisis yang dilakukan berupa analisis kadar abu dan sulfur dengan metode proksimat yang mengacu pada ASTM D7582-12, analisis $x$-ray diffraction $(X R D)$, analisis maseral dengan metode petrografi sayatan poles yang mengikuti klasifikasi menurut ICCP 1994; Sykorova dan Pickel, dkk., (2004); Pickel dan Kus, (2017) dan analisis geokimia dengan metode ICPMSIAES.

\section{GEOLOGI}

Daerah penelitian berada di Cekungan Sumatera Selatan yang merupakan cekungan busur belakang dan terbentuk sebagai hasil interaksi Lempeng IndoAustralia dan Lempeng mikro-Sunda (de Coster, 1974). Cekungan Sumatera Selatan tersusun oleh batuan sedimen Tersier yang terendapkan secara tidakselaras di atas batuan metamorf dan batuan beku Pra-Tersier (Bishop, 2001). Menurut Barber (2005), secara fisiografis cekungan ini berarah barat laut-tenggara, yang dibatasi oleh Bukit Barisan di sebelah barat daya, Pegunungan Tiga Puluh di sebelah barat laut, Paparan Sunda di sebelah timur laut, dan Tinggian Lampung di sebelah tenggara. Batas barat daya Cekungan Sumatera Selatan yang dibatasi oleh Bukit Barisan merupakan penciri akhir siklus Neogen Tua (Oligosen AkhirMiosen) proses vulkanisme di Sumatera yang ditandai dengan pengangkatan batuan Pra-Tersier pada Miosen Tengah (van Bemmelen, 1949 dalam Barber, 2005). Hal ini menunjukkan terdapat keterkaitan proses pengisian material sedimen pada Cekungan Sumatera Selatan dengan proses vulkanisme Tersier di Sumatera (Gambar 3). Penelitian berfokus pada Formasi Muara Enim sebagai formasi pembawa lapisan batubara. Formasi ini terbentuk pada Miosen Akhir-Pliosen Awal (Baumann, 1973 dalam Shell Minjbouw 1978). Formasi ini diendapkan secara menjari dengan Formasi Air Benakat dengan ketebalan berkisar 450 sampai $750 \mathrm{~m}$. Proses pengendapan Formasi Muara Enim diawali pada lingkungan laguna dan berubah menjadi lingkungan delta dan tidal flat (Pujobroto, 1997). Menurut Amijaya dan Littke (2005), secara umum pada Formasi Muara Enim dijumpai batulempung, batulanau, dan beberapa lapisan batupasir dengan lapisan batubara dengan ketebalan maksimal mencapai $140 \mathrm{~m}$. Selama pembentukan Formasi Muara Enim pada Miosen Akhir hingga Pliosen Awal (Baumann, 1973 dalam Shell Minjbouw, 1978) detritus vulkanik terbawa dan terendapkan pada saat terjadi proses pengendapan, yang diindikasikan dengan lapisan tonstein. Tonstein yang terendapkan ini merupakan bukti peningkatan aktivitas vulkanisme (Pujobroto, 1997). 


\section{MAKALAH ILMIAH}

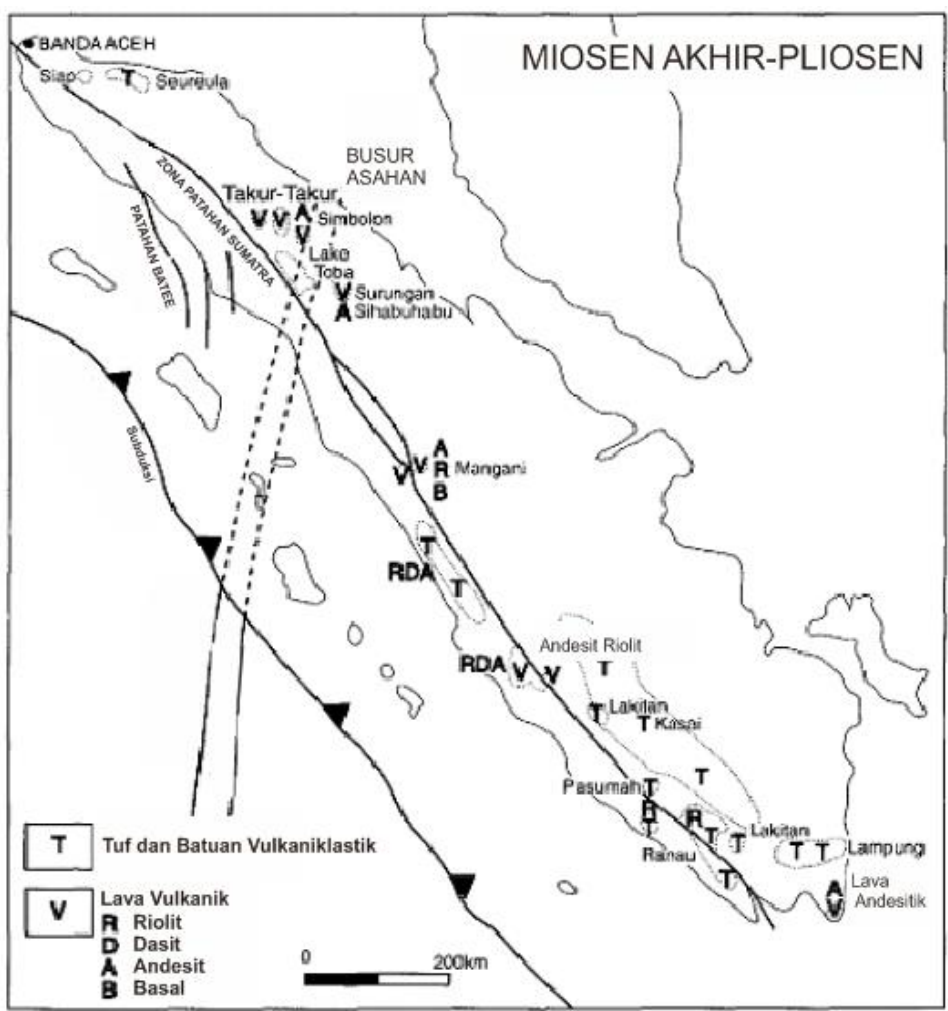

Gambar 3. Peta persebaran material vulkanik proses vulkanisme Tersier periode Miosen Akhir hingga Pliosen di Sumatera (Barber, 2005)

\section{HASIL}

\section{Data Lapangan}

Hasil identifikasi di lapangan diperoleh data lapangan berupa deskripsi litologi, kolom stratigrafi rinci, dan pengambilan conto batubara dan non-batubara. Batubara yang terdapat di lokasi pengamatan terdiri atas 2 lapisan, yakni $\mathrm{A} 1$ dan $\mathrm{A} 2$. Kedua lapisan tersebut dibatasi oleh lapisan parting berupa batupasir tufaan yang memiliki ketebalan $4 \mathrm{~m}$.

Masing-masing lapisan batubara yang diamati memiliki clay band dengan ketebalan 3-20 cm, yakni clay bands 1,2 , dan 3 pada Lapisan Batubara A1, sedangkan pada A2 terdapat clay band 4 . Keseluruhan clay band berperan sebagai parting atau lapisan pengotor di antara perlapisan batubara dengan litologi batulempung tufaan. Kolom stratigrafi di lokasi pengamatan dapat dilihat pada Gambar 4.

\section{Analisis Mineralogi}

Berdasarkan hasil analisis mineralogi dengan pengamatan megaskopis, petrografi sayatan poles, dan XRD (Tabel 1) secara umum conto batubara dan non-batubara di lokasi penelitian didominasi oleh mineral berikut:

\section{Kuarsa}

Kuarsa ditemukan dijumpai berbentuk butir melimpah pada parting, yakni pada litologi batupasir tufaan dan batulempung tufaan maupun mengisi rekahan pada conto batubara.

\section{Pirit}

Pirit dijumpai berbentuk butir dan mengisi rekahan pada conto batubara. Mineral ini hadir dengan kelimpahan yang lebih sedikit daripada kuarsa.

\section{Kaolinit}

Kaolinit dijumpai hampir pada setiap conto clay band, yang dicirikan dengan nilai d $7.27,4.32,3.58$ dan nilai 2-theta 12.3, 20.34, 24.82 (Gambar 5). 


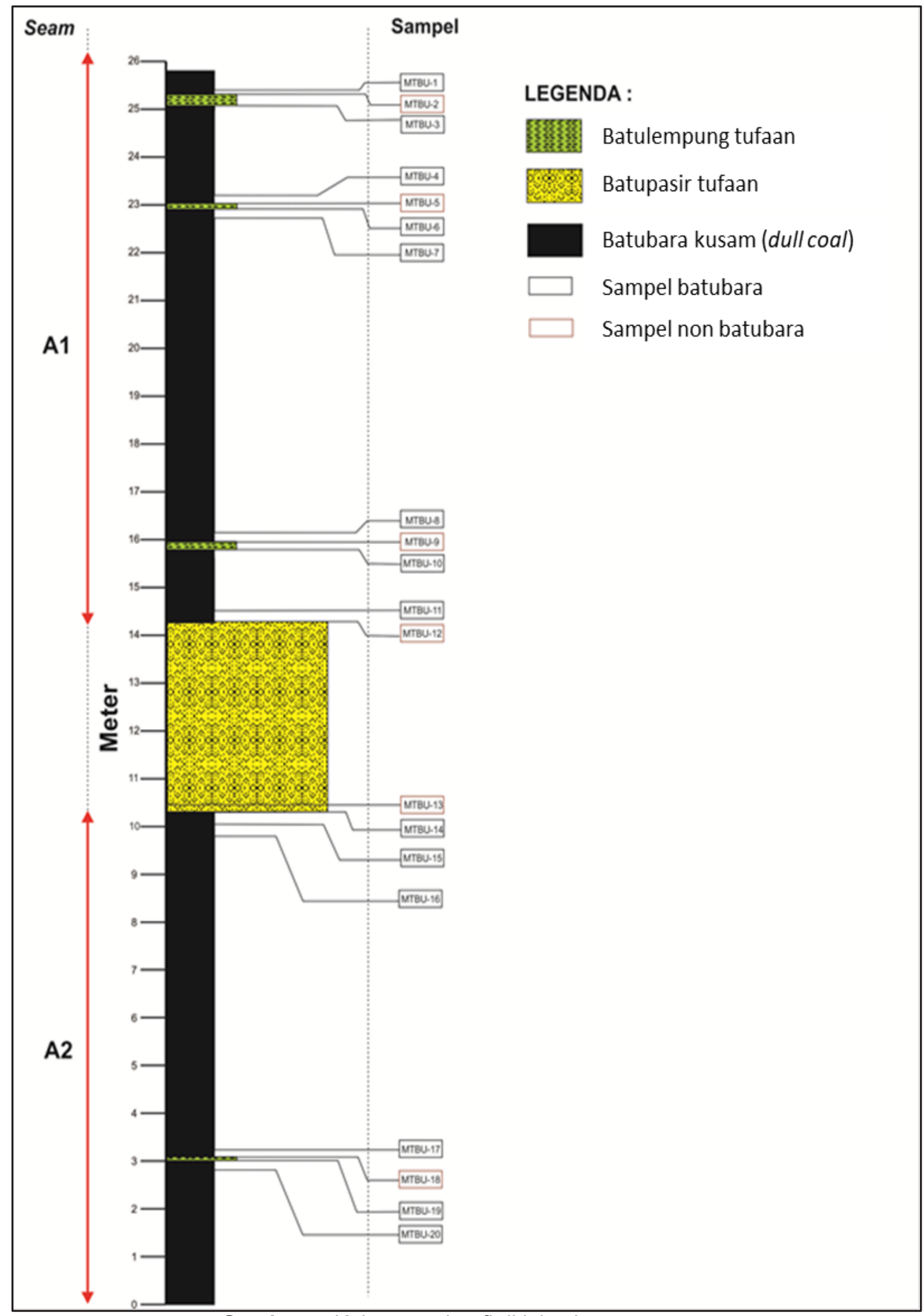

Gambar 4. Kolom stratigrafi di lokasi pengamatan 


\section{MAKALAH ILMIAH}

Tabel 1. Hasil analisis mineralogi dengan metode $X R D$ pada conto non-batubara

\begin{tabular}{cccc}
\hline Lapisan & Conto & Litologi & Mineral \\
\hline A1 & MTBU-02 & Batulempung tufaan & Kuarsa, Kaolinit \\
\hline A1 & MTBU-05 & Batulempung tufaan & Kuarsa, Kaolinit \\
\hline A1 & MTBU-09 & Batulempung tufaan & Kuarsa, Kaolinit \\
\hline A2 & MTBU-12 & Batupasir tufaan & Kuarsa, Kaolinit \\
\hline A2 & MTBU-13 & Batupasir tufaan & Kuarsa, Kaolinit \\
\hline
\end{tabular}

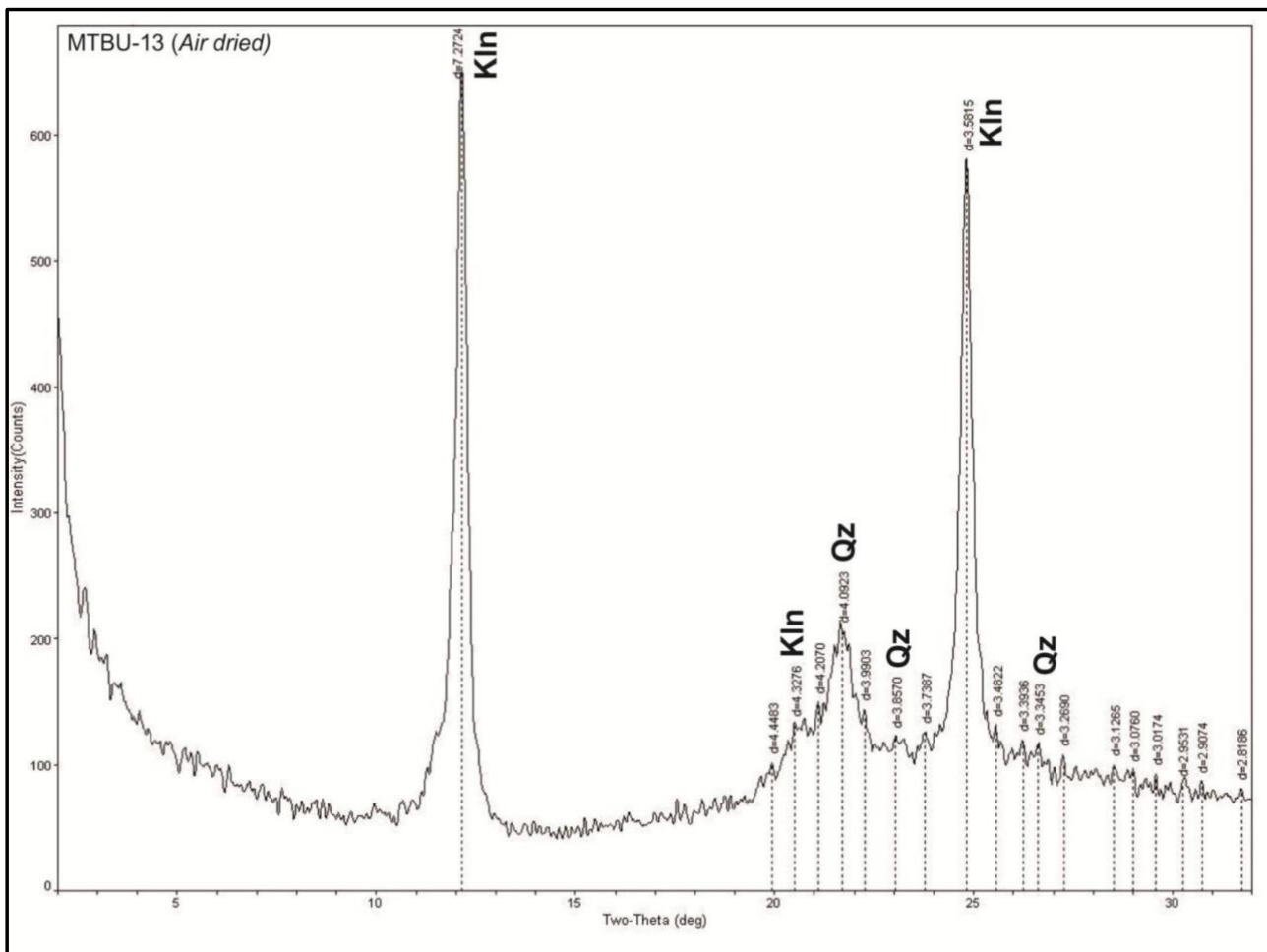

Gambar 5. Diagram hasil analisis XRD

\section{Analisis Maseral}

Berdasarkan hasil pengamatan sayatan poles menggunakan mikroskop reflektan (white light dan fluorescence) pada 14 conto batubara diperoleh kandungan maseral terdiri atas kelompok maseral huminit, liptinit dan inertinit (Gambar 7 dan Gambar 8). Keterdapatan maseral pada keseluruhan conto didominasi oleh maseral huminit $(48,9$ s.d. $81,8 \%)$, diikuti oleh kelompok maseral liptinit $(8,7$ s.d. $31,3 \%)$ dan kelompok maseral inertinit $(4,9$ s.d. $17,5 \%)$

\section{Analisis Kadar Abu dan Sulfur}

Batubara di daerah penelitian memiliki kadar abu dan sulfur yang rendah (Gambar 6). Berdasarkan hasil analisis diperoleh rata-rata nilai kadar abu $3,45 \%$ dan rata- rata kadar sulfur $0,92 \%$. Hal tersebut mencirikan batubara yang umum dijumpai di daerah Tanjung Enim.

\section{Analisis Geokimia}

Analisis geokimia bertujuan untuk mengetahui komposisi batubara berupa konsentrasi UTJ dan senyawa oksida utama. UTJ yang dianalisis adalah $\mathrm{La}, \mathrm{Ce}$, $\mathrm{Pr}, \mathrm{Nd}, \mathrm{Sm}, \mathrm{Eu}, \mathrm{Gd}, \mathrm{Tb}, \mathrm{Dy}, \mathrm{Y}, \mathrm{Ho}, \mathrm{Er}, \mathrm{Tm}$, $\mathrm{Yb}$, dan Lu (Tabel 2). Konsentrasi UTJ berkisar dari 15,51 ppm s.d. 203,72 ppm. Senyawa oksida utama yang dianalisis adalah $\mathrm{SiO}_{2}, \mathrm{Al}_{2} \mathrm{O}_{3}, \mathrm{Fe}_{2} \mathrm{O}_{3}, \mathrm{CaO}, \mathrm{MgO}$, $\mathrm{Na}_{2} \mathrm{O}, \mathrm{K}_{2} \mathrm{O}, \mathrm{Cr}_{2} \mathrm{O}_{3}, \mathrm{TiO}_{2}, \mathrm{MnO}, \mathrm{P}_{2} \mathrm{O}_{5}, \mathrm{SrO}$, dan $\mathrm{BaO}$. Kelimpahan dinyatakan dalam bentuk wt\% (weight percent). Hasil analisis menunjukkan masing-masing conto memiliki kelimpahan $\mathrm{SiO}_{2}$ dan $\mathrm{Al}_{2} \mathrm{O}_{3}$ yang dominan (Tabel 3). 


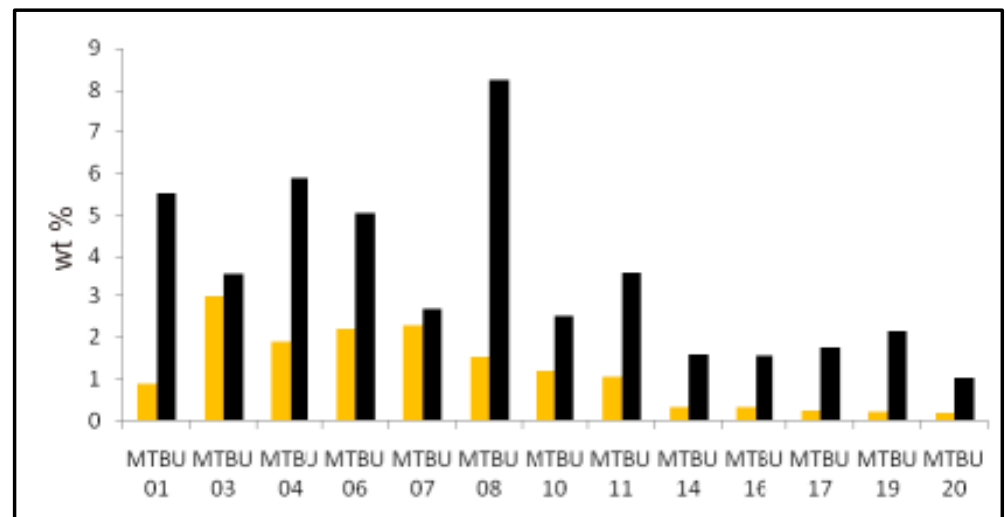

Gambar 6. Kadar abu dan kadar sulfur pada keseluruhan conto batubara (wt \%)
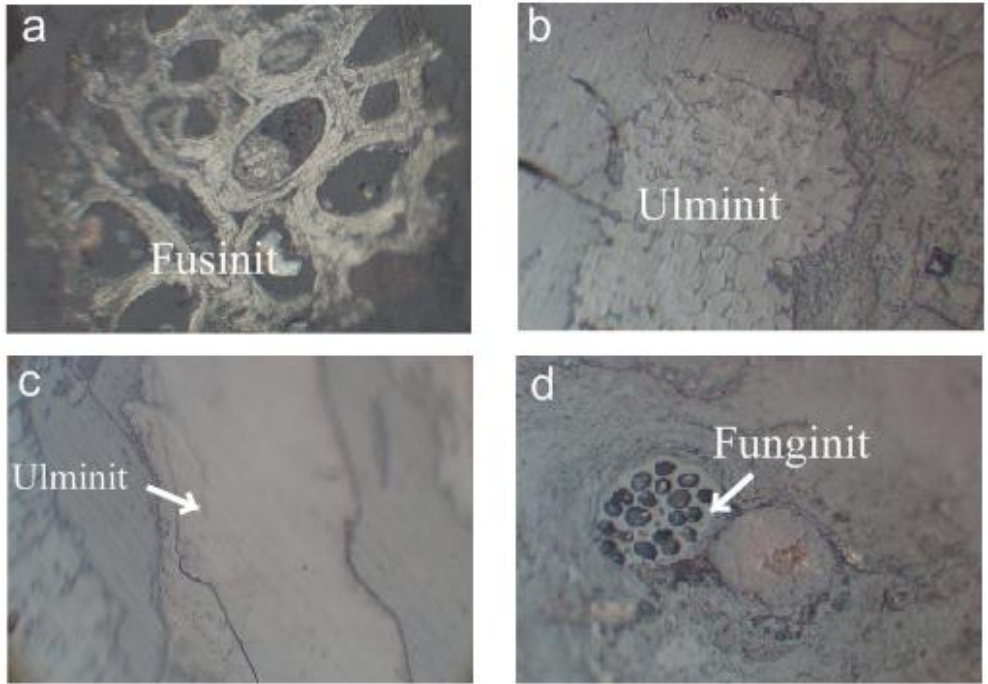

Gambar 7. Kenampakan petrografi sayatan poles maseral grup inertinit: fusinit (a), funginit (d) dan grup huminit: ulminit (b dan $\mathrm{c}$ )
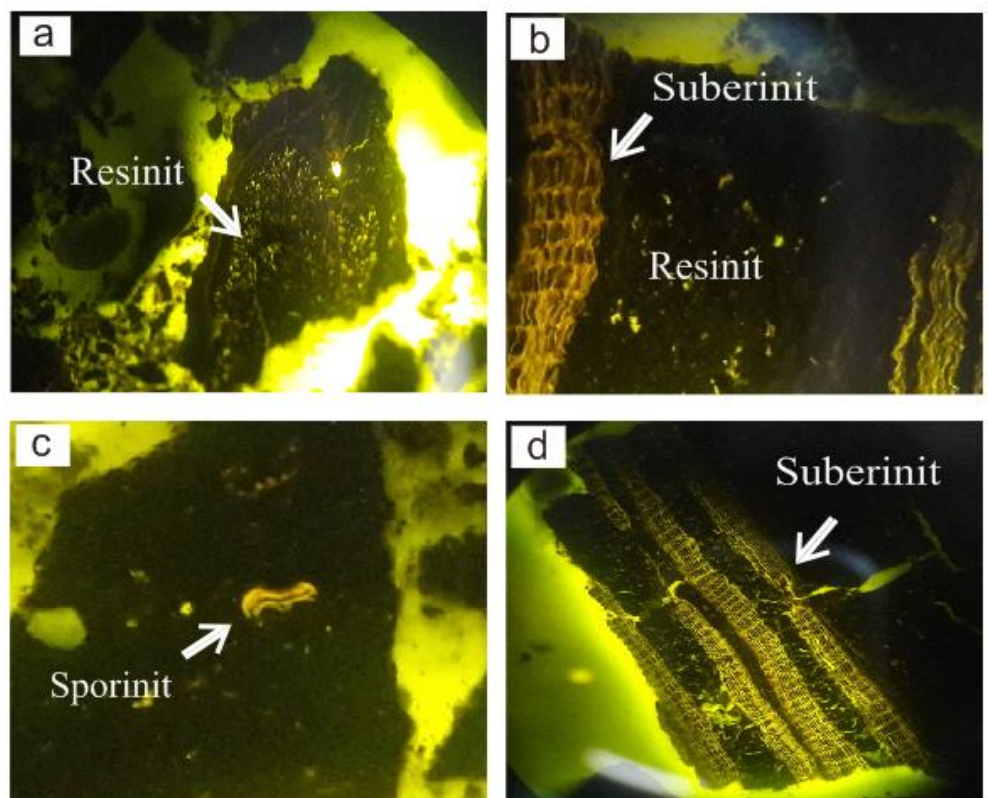

Gambar 8. Kenampakan petrografi sayatan poles kelompok maseral liptinit, resinit (a), resinit dan suberinit (b), sporinit (c), dan suberinit (d) 


\section{MAKALAH ILMIAH}

Tabel 2. Konsentrasi UTJ pada keseluruhan conto

\begin{tabular}{|c|c|c|c|c|c|c|c|c|c|c|c|c|c|c|c|c|c|c|}
\hline No & $\begin{array}{c}\text { Lapisan } \\
\text { Batubara }\end{array}$ & Sampel & $\begin{array}{c}\text { La } \\
\text { ppm }\end{array}$ & $\begin{array}{c}\mathrm{Ce} \\
\mathrm{ppm}\end{array}$ & $\begin{array}{c}\mathrm{Pr} \\
\mathrm{ppm}\end{array}$ & $\begin{array}{l}\text { Nd } \\
\mathrm{ppm}\end{array}$ & $\begin{array}{l}\text { Sm } \\
\mathrm{pgm}\end{array}$ & $\begin{array}{c}\mathbf{E u} \\
\mathrm{ppm}\end{array}$ & $\begin{array}{l}\text { Gd } \\
\mathrm{ppm}\end{array}$ & $\begin{array}{c}\text { Tb } \\
\text { ppm }\end{array}$ & $\begin{array}{l}\text { Dy } \\
\text { ppm }\end{array}$ & $\begin{array}{c}\mathbf{Y} \\
\mathrm{ppm}\end{array}$ & $\begin{array}{r}\mathrm{Ho} \\
\mathrm{ppm}\end{array}$ & $\begin{array}{c}\mathbf{E r} \\
\mathrm{ppm}\end{array}$ & $\begin{array}{r}\mathbf{T m} \\
\mathrm{ppm}\end{array}$ & $\begin{array}{l}\mathrm{Yb} \\
\mathrm{ppm}\end{array}$ & $\begin{array}{l}\mathbf{L u} \\
\mathrm{ppm}\end{array}$ & $\begin{array}{c}\text { TOTAL } \\
\text { REE }\end{array}$ \\
\hline 2 & Al & MTBU 02 & 5,7 & 9.5 & 1,09 & 4,1 & 1,25 & 0,25 & 0.91 & 0,21 & 1,18 & 7,2 & 0,29 & 0,92 & 0,15 & 1,07 & 0,17 & 33,99 \\
\hline 4 & Al & MTBU 04 & 5,4 & 15,3 & 2,28 & 8,7 & 2,58 & 0,63 & 2,39 & 0,45 & 2,55 & 10,2 & 0,51 & 1,52 & 0,24 & 1,45 & 0,18 & 54,38 \\
\hline 5 & Al & MTBU 05 & 3,9 & 8,7 & 1,21 & 4 & 1,12 & 0,19 & 1,03 & 0,23 & 1,68 & 8,8 & 0,35 & 1,17 & 0,16 & 1,33 & 0,19 & 34,06 \\
\hline 6 & Al & MTBU 06 & 4,4 & 12,4 & 1,88 & 6,9 & 1,96 & 0,55 & 1,96 & 0,38 & 2,24 & 9,1 & 0,47 & 1,13 & 0,17 & 1,14 & 0,15 & 44,83 \\
\hline 9 & Al & MTBU 09 & 2,4 & 5,1 & 0,61 & 2,6 & 0,57 & 0,11 & 0,51 & 0,09 & 0,61 & 3,8 & 0,14 & 0,58 & 0,11 & 0,58 & 0,14 & 17,95 \\
\hline 10 & Al & MTBU 10 & 4 & 8,2 & 1,07 & 3,9 & 0,85 & 0,32 & 1,0 & 0,21 & 1,33 & 7,7 & 0,33 & 0,94 & 0,14 & 0,95 & 0,15 & 31,1 \\
\hline 11 & A1 & MTBU 11 & 29,1 & 56,4 & 6,91 & 24,4 & 5,29 & 1,53 & 5,78 & 1,25 & 8,6 & 48,9 & 1,85 & 559 & 0,91 & 6,23 & 0,98 & 203,72 \\
\hline 12 & A2 & MTBU 12 & 36 & 69,3 & 8,12 & 26,9 & 4,85 & 0.75 & 4,94 & 0,83 & 4,59 & 25,8 & 0,92 & 2,82 & 0,41 & 2,57 & 0,36 & 189,16 \\
\hline 13 & A2 & MTBU 13 & 8,1 & 13,8 & 1,45 & 5,4 & 0,91 & 0,23 & 1,01 & 0,17 & 1,3 & 8,3 & 0,3 & 0,95 & 0,16 & 1,19 & 0,22 & 43,49 \\
\hline 14 & A2 & & 20,8 & 43,3 & 5,46 & 18,7 & 4,56 & 1,09 & 4,27 & 0,84 & 0 & 29,7 & 1,24 & 3,86 & 0,57 & 4,44 & 0,58 & 145,11 \\
\hline 19 & A2 & MTBU 19 & 2,6 & 4,8 & 0,63 & 2,5 & 0,49 & 0,09 & 0,66 & 0,06 & 0,56 & 3,6 & 0,1 & 0,28 & 0,08 & 0,5 & 0,07 & 17,02 \\
\hline 20 & $\mathrm{~A} 2$ & MTBU 20 & 2,3 & 4,4 & 0,63 & 2,2 & 0,57 & 0,13 & 0,49 & 0,08 & 0,36 & 3,4 & 0,08 & 0,33 & 0,04 & 0,44 & 0,06 & 15,51 \\
\hline
\end{tabular}

Batubara $\longrightarrow$ Batupasir

Batulempung

Batulempung

Tabel 3. Konsentrasi senyawa oksida utama pada keseluruhan conto

\begin{tabular}{|c|c|c|c|c|c|c|c|c|c|c|c|c|c|c|c|c|c|}
\hline $\mathrm{No}_{\mathrm{F}}$ & $\begin{array}{c}\text { Lapisan } \\
\text { Batubara }\end{array}$ & Sampel & $\mathrm{SiO}_{2}$ & $\mathrm{Al}_{2} \mathrm{O}_{3}$ & $\mathrm{Fe}_{2} \mathrm{O}_{3}$ & $\mathrm{CaO}$ & $\mathrm{MgO}$ & $\mathrm{Na}_{2} \mathrm{O}$ & $\mathrm{K}_{2} \mathrm{O}$ & $\mathrm{Cr}_{2} \mathrm{O}_{3}$ & $\mathrm{TiO}_{2}$ & $\mathrm{MnO}$ & $\mathrm{P}_{2} \mathrm{O}_{5}$ & SrO & $\mathrm{BaO}$ & $\begin{array}{c}\text { Total Major } \\
\text { Oxides }\end{array}$ & LOI \\
\hline 1 & $\mathrm{Al}$ & MTBU 01 & 53,18 & 37,26 & 5,57 & 1,27 & 0,64 & 0,16 & 0,48 & 0,03 & 1,43 & 0,16 & 0,16 & 0,16 & 0,16 & 6,28 & 93,5 \\
\hline 2 & Al & MTBU 02 & 54.21 & 41.85 & 2.47 & 0.10 & 0.16 & 0.01 & 0.20 & 0.00 & 0.92 & 0.04 & 0.01 & 0.01 & 0.01 & 73.59 & 24.8 \\
\hline 3 & Al, & MTBU 03 & 48,81 & 38,19 & 10,18 & 1,11 & 0,45 & 0,07 & 0.22 & 0,01 & 0,89 & 0,07 & 0,07 & 0,07 & 0,07 & 13,46 & 85,8 \\
\hline 4 & Al: & MTBU 04 & 52,35 & 39,13 & 3,36 & 2,15 & 0,67 & 0,13 & 0,74 & 0,01 & 1,41 & 0,13 & 0.07 & 0.07 & 0,07 & 14,92 & 85,1 \\
\hline 5 & Al & MTBU 05 & 52.28 & 39,08 & 3.35 & 2.14 & 0.67 & 0.13 & 0.74 & 0.01 & 1.41 & 0.13 & 0.07 & 0.07 & 0.07 & 75.68 & 22.9 \\
\hline 6 & Al, & MTBU 06 & 56,42 & 40,43 & 1,33 & 0,12 & 0,15 & 0,03 & 0.16 & 0,00 & 1,31 & 0,01 & 0,03 & 0,01 & 0,01 & 6.95 & 92,9 \\
\hline 7 & A1, & MTBU 07 & 43,31 & 38,56 & 11,08 & 4,17 & 1,58 & 0,14 & 0,29 & 0,03 & 0,58 & 0,29 & 0,14 & 0,14 & 0,14 & 2,8 & 97 \\
\hline 8 & Al, & MTBU 08 & 25.00 & 22.14 & 42,14 & 7.50 & 2,14 & 0.36 & 0,36 & 0.07 & 0.36 & 0,36 & 0.36 & 0,36 & 0.36 & 9.37 & 90.4 \\
\hline 9 & Al $\mathrm{A}$ & MTBU 09 & 54.72 & 4320 & 0.35 & 0.12 & 0.10 & 0.01 & 0.07 & 0.00 & 134 & 0.01 & 0.03 & 0.01 & 0.01 & 76.35 & 233 \\
\hline 10 & Al $\mathrm{A}$ & MTBU 10 & 34,42 & 39,29 & 15,91 & 6,82 & 2,27 & 0,32 & 0,32 & 0,06 & 0,65 & 0,65 & 0.32 & 0,32 & 0,32 & 3,08 & 96.8 \\
\hline 11 & A1 $\mathrm{B}$ & MTBU II & 35,91 & 2839 & 33,11 & 1,03 & 0,37 & 0,07 & 0,15 & 0,01 & 0,96 & 0,07 & 0,07 & 0,07 & 0,07 & 13.56 & 85,8 \\
\hline 12 & A1 $\mathrm{N}$ & MTBU 12 & 64,52 & 33,79 & $0, \pi$ & 0,04 & 0,14 & 0,02 & 0,13 & 0,00 & 0,56 & 0,01 & 0,02 & 0,01 & 0,01 & 85,24 & 15,15 \\
\hline 13 & A2 $\quad$ & MTBU 13 & 75.33 & 21.53 & 2.31 & 0.10 & 0.20 & 0.02 & 0.14 & 0.00 & 0.35 & 0.01 & 0.01 & 0.01 & 0.01 & 88,01 & 13.2 \\
\hline 14 & A2 $\quad$ & MTBU 14 & 58,32 & 37,67 & 1,82 & 0,85 & 0,36 & 0,12 & 0.12 & 0,02 & 0,73 & 0,12 & 0,12 & 0,12 & 0,12 & 8,23 & 91,3 \\
\hline 15 & A2 $\mathrm{N}$ & MTBU 15 & 97,78 & 1,47 & 0,47 & 0,06 & 0,04 & 0,03 & 0,10 & 0,00 & 0,03 & 0,01 & 0,01 & 0,01 & 0,01 & 78,75 & 22,9 \\
\hline 16 & A2 $\quad$ & MTBU 16 & 56,69 & 33,07 & 5,12 & 3,15 & 0,79 & 0,39 & 0,39 & 0,08 & 0,39 & 0,39 & 0,39 & 0,39 & 0.39 & 2,54 & 97,2 \\
\hline 17 & A2 $\quad$ S & MTBU 17 & 71,78 & 17,79 & 5,52 & 2,04 & 0,20 & 0.20 & 0,20 & 0,04 & 0,41 & 0,20 & 1,84 & 0,41 & 0,20 & 4,89 & 93,4 \\
\hline 18 & $A 2$, & MTBU 18 & 75.82 & 2032 & 1.72 & 0.06 & 0.24 & 0.04 & 0.57 & 0.01 & 1.13 & 0.02 & 0.08 & 0.02 & 0.02 & 49.463 & 49 \\
\hline 19 & A2 $\quad$ & MTBU 19 & 54,18 & 38,70 & 3,72 & 1,55 & 0,31 & 0,31 & 0,31 & 0,06 & 0,93 & 0,31 & 0,31 & 0.31 & 0,31 & 3,23 & 969 \\
\hline 20 & $\mathrm{~A} 2 \mathrm{~N}$ & MTBU 20 & 59.48 & 30.07 & 5.88 & 2,29 & 0,33 & 0,33 & 0.65 & 0,07 & 0,98 & 0,33 & 0.33 & 0.33 & 0.33 & 3,06 & 96.4 \\
\hline
\end{tabular}

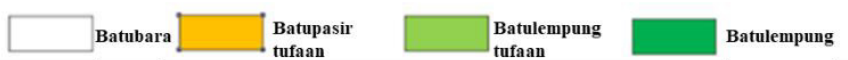

\section{PEMBAHASAN}

\section{Konsentrasi UTJ Batubara}

Nilai total konsentrasi UTJ pada keseluruhan conto berkisar $15,51 \mathrm{ppm}$ s.d. 203,72 ppm (Gambar 10). Terdapat empat conto batubara dan non-batubara yang mengalami pengayaan konsentrasi UTJ jika dibandingkan dengan konsentrasi UTJ alami pada batubara menurut Ketris dan Yudovich (2009) yakni 68,5 ppm. Pengayaan konsentrasi UTJ pada conto batubara terdapat pada conto MTBU-11 (203,72 ppm) dan conto batubara MTBU$14(145,11 \mathrm{ppm})$. Conto non batubara yang mengalami pengayaan memiliki nilai konsentrasi tertinggi pada conto MTBU-12 dengan litologi batupasir tufaan $(189,16$ ppm) diikuti oleh conto MTBU-18 (118,47 ppm) dengan litologi batulempung tufaan (Tabel 2). Keterdapatan UTJ pada conto diklasifikasikan pada 3 jenis UTJ yakni UTJ Ringan (Light Rare Earth Elements/LREE), UTJ Menengah (Medium Rare Earth Elements/MREE), dan UTJ Berat (Heavy 
Rare Earth Elements/HREE) menurut Seredin dan Dai (2012). Nilai konsentrasi UTJ selanjutnya dinormalisasi dengan nilai konsentrasi UTJ pada Upper Continental Crust (UCC).

Hasil analisis data konsentrasi UTJ menunjukkan UTJ pada keseluruhan conto didominasi oleh jenis UTJ Berat (HREE) $(44,21 \%)$ kemudian diikuti oleh UTJ Menengah (MREE) (35,02\%), dan UTJ Ringan (LREE) (20,78\%). Conto batubara dengan nilai konsentrasi tertinggi (MTBU11 dan MTBU-14) memiliki nilai konsentrasi yang lebih tinggi dibandingkan dengan nilai rata-rata konsentrasi UTJ pada batubara dunia menurut Ketris dan Yudovich (2009) dan batubara Cina (Dai dan Ren, 2012) (Gambar 9).

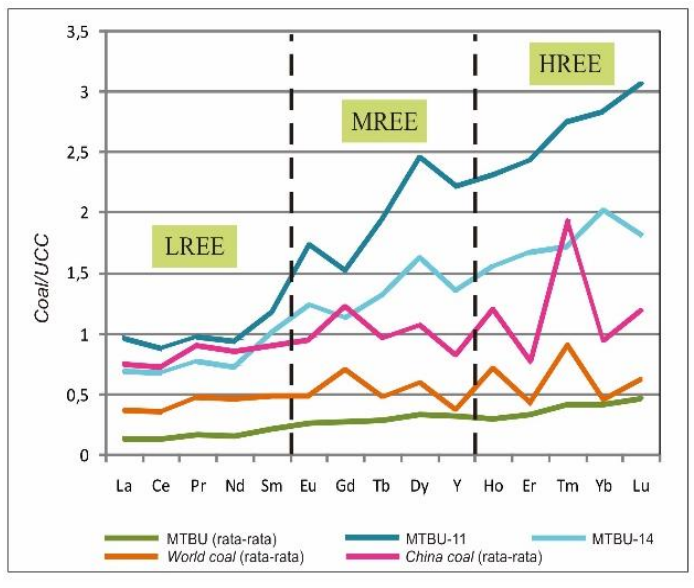

Gambar 9. Komparasi nilai konsentrasi UTJ pada batubara conto MTBU-11, MTBU-14, batubara Cina (Dai dan Ren, 2012) dan batubara dunia (Ketris dan Yudovich, 2009)

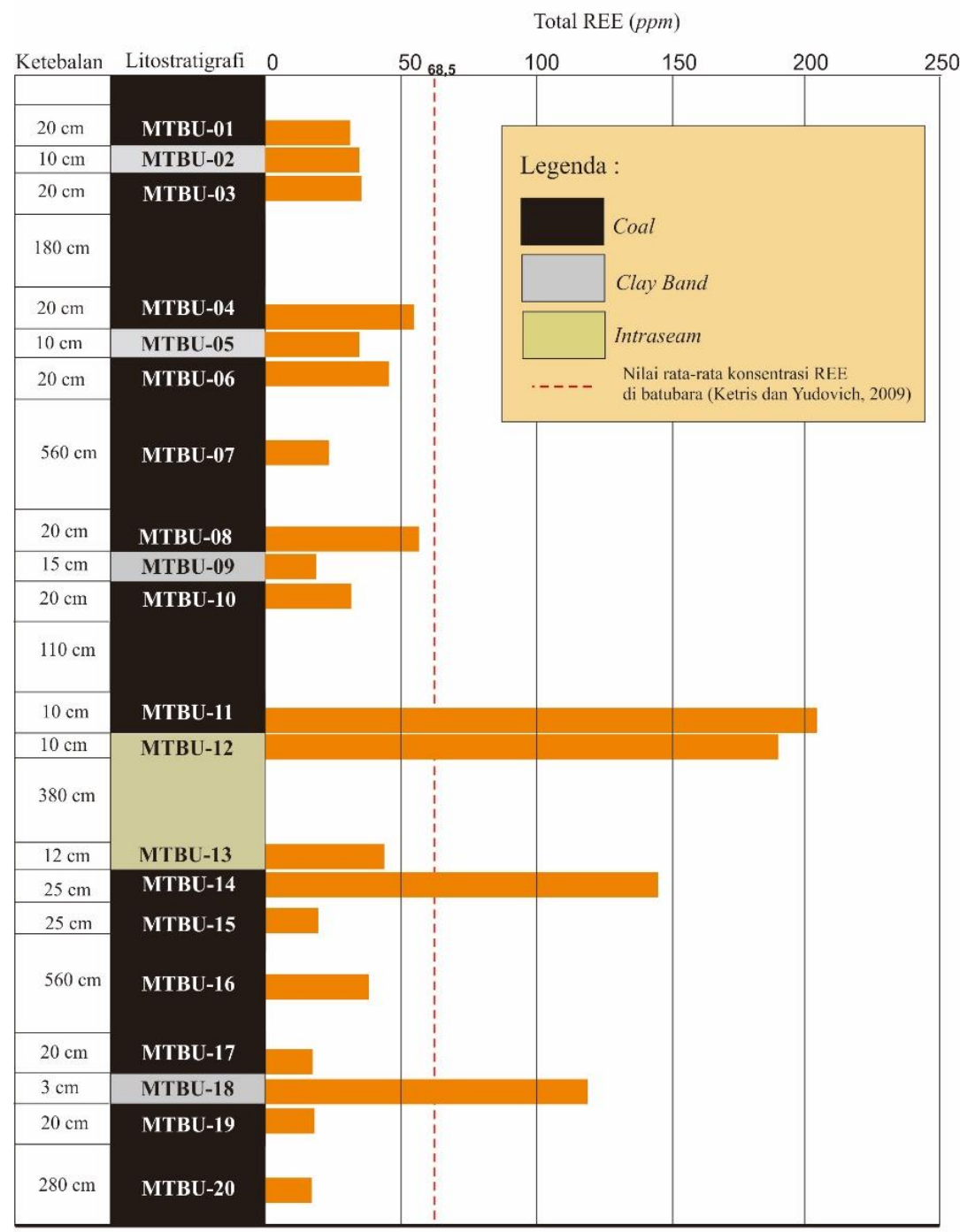

Gambar 10. Persebaran nilai konsentrasi UTJ pada keseluruhan conto 


\section{Evaluasi Pengayaan Batubara}

Kondisi geologis tertentu dapat menyebabkan pengayaan UTJ dengan faktor yang mengontrol meliputi geokimia batuan sumber dari darat, kandungan fluida hidrotermal, pengaruh lingkungan laut, material vulkanik, dan lingkungan pengendapan gambut (Dai dan Graham, 2017). Nilai konsentrasi UTJ ditinjau dengan berbagai paramater untuk mengkaji prospek pengayaannya.

\section{Perhitungan nilai REO ash}

Prospek industri pengayaan UTJ dapat ditinjau dengan nilai cut-off grade pada abu batubara $\left(\mathrm{REO}_{\text {ash }}\right)$ adalah $\geq 1.000 \mathrm{ppm}$ atau $\geq 800$ ppm untuk lapisan batubara dengan ketebalan $>5$ meter (Dai dan Graham, 2017). Analisis proksimat yang dilakukan menghasilkan data kadar abu yang digunakan untuk perhitungan konsentrasi UTJ pada abu (REO ash). Perhitungan dilakukan pada keseluruhan conto dan ditinjau hasil perhitungan pada 3 conto bulk, yakni MTBU-04, MTBU-07, MTBU-08, dan pada conto dengan konsentrasi UTJ tertinggi, yakni MTBU-11 dan MTBU-14. Data yang diperoleh menunjukkan adanya pengayaan UTJ yang memenuhi nilai cutoff grade pada conto MTBU-07, MTBU-11, dan MTBU-14 (Gambar 11).

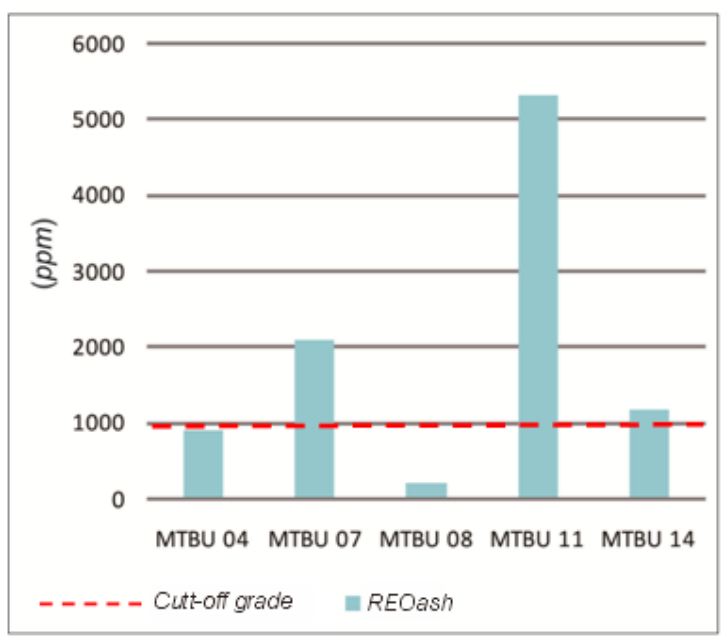

Gambar 11. Perbandingan konsentrasi UTJ pada conto MTBU, world coal (Ketris dan Yudivich, 2009), dan China coal (Dai dan Ren, dkk., 2012)

\section{Perhitungan nilai $\mathrm{C}_{\text {outl }}$ dan $R E E_{\text {def-rel }}$}

Selain memenuhi nilai cutt-off grade, prospek pengayaan UTJ menurut tren pasar (dalam lingkup industri) ditinjau menggunakan perhitungan $\mathrm{C}_{\text {outl }}$ dan $R E E_{\text {def-rel. }}$ Perhitungan tersebut dilakukan untuk melihat apakah deposit UTJ mengandung unsur UTJ yang langka semaksimal mungkin. Menurut perhitungan yang dilakukan, dijumpai nilai $\mathrm{C}_{\text {out }}$ tertinggi pada conto batubara MTBU-6 dengan nilai 1,20 dan rata-rata nilai $C_{\text {outl }} 0,82$. Nilai tersebut menunjukkan bahwa batubara di daerah MTBU mengandung lebih banyak unsur yang jarang ditemukan mengacu pada klasifikasi menurut Dai dan Graham, (2017) nilai $C_{\text {outl }} 0,7 \leq C_{\text {outl }} \leq 2,4$ berada pada klasifikasi promising area. Nilai perhitungan $\mathrm{C}_{\text {outl }}$ kemudian diplot bersama nilai $R E E_{\text {def- }}$ rel (critical REE/total REE) pada diagram menurut Seredin dan Dai, (2012).

Diagram yang dihasilkan menunjukkan konsentrasi UTJ pada conto secara dominan termasuk pada promising area (cluster II) yang dicirikan dengan nilai 30\% $\leq R E E_{\text {def-rel }} \leq 51 \%$. Hal tersebut merupakan potensi yang baik pada skala industri dan telah diterapkan pada deposit Hutoshan dan Kutessay (Gambar 12).

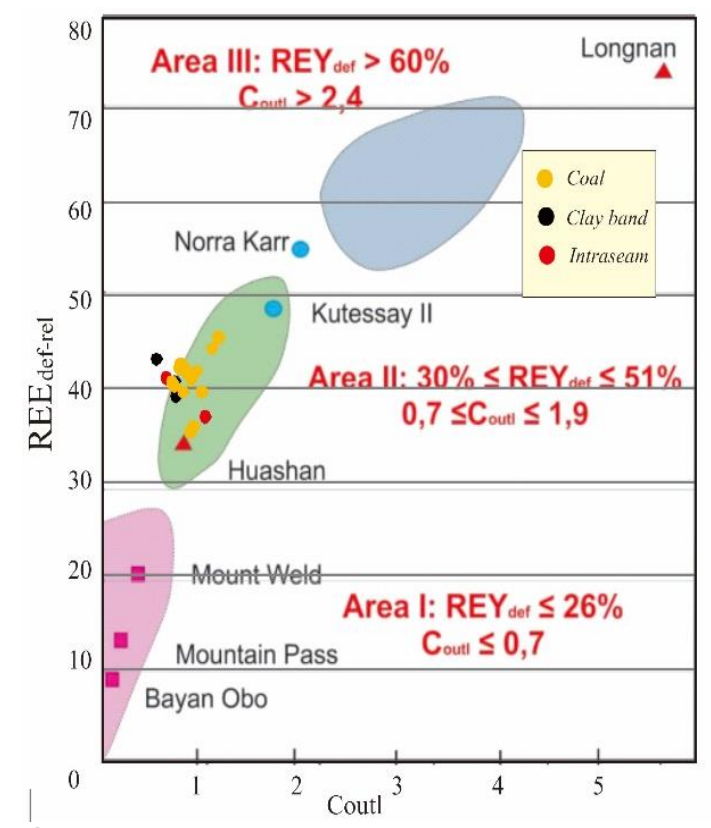

Gambar 12. Plot diagram REE $E_{\text {def-rel }}$ dan $\mathrm{C}_{\text {outl }}$ menurut Dai dan Finkleman (2018) 
Evaluasi pengayaan UTJ berdasarkan perhitungan $\mathrm{C}_{\text {outl }}$ selanjutnya ditinjau menggunakan diagram $\mathrm{C}_{\text {outl }}$ dan nilai $\mathrm{REO}_{\text {ash }}$ menurut Dai dan Finkleman (2018) pada conto bulk dan conto dengan konsentrasi UTJ tertinggi. Diagram yang dihasilkan mendukung nilai konsentrasi UTJ termasuk pada klasifikasi promising area kecuali pada conto MTBU-04 dan MTBU-08 yang memiliki nilai $\mathrm{REO}_{\text {ash }}$ di bawah 1000 ppm (Gambar 13).

\section{Perhitungan Concentration coefficient}

Parameter untuk mengkaji pengayaan individu UTJ dapat diklasifikasikan menurut Dai dan Graham, (2017) berdasarkan perhitungan concentration coefficient (CC). CC merupakan rasio konsentrasi UTJ pada batubara yang diidentifikasi/rasio rata-rata nilai UTJ pada batubara dunia menurut Ketris dan Yudovich (2009). Klasifikasi tersebut membagi pengayaan UTJ menjadi unusually enriched (CC>100), significantly enriched $\quad(10<\mathrm{CC}<100), \quad$ enriched $(5<\mathrm{CC}<10)$, sligthly enriched $(2<\mathrm{CC}<5)$, normal $(0,5<\mathrm{CC}<2)$, depleted $(\mathrm{CC}<0,5)$. Berdasarkan hasil perhitungan diperoleh rata-rata conto MTBU pada keseluruhan unsur UTJ Ringan, yakni (La, Ce, Pr, Nd, dan $\mathrm{Sm}$ ) yang masuk pada klasifikasi terkayakan, kecuali pada unsur Sm. Unsur UTJ Menengah Eu, Dy, $Y$ tergolong klasifikasi normal, dan unsur $\mathrm{Gd}$ dan $\mathrm{Tb}$ depleted. Unsur UTJ Berat secara umum tergolong slightly enriched, yakni $\mathrm{Ho}, \mathrm{Er}$, dan Lu berada pada klasifikasi normal, sedangkan $\mathrm{Tm}$ dan $\mathrm{Yb}$ terkayakan (Gambar 14).

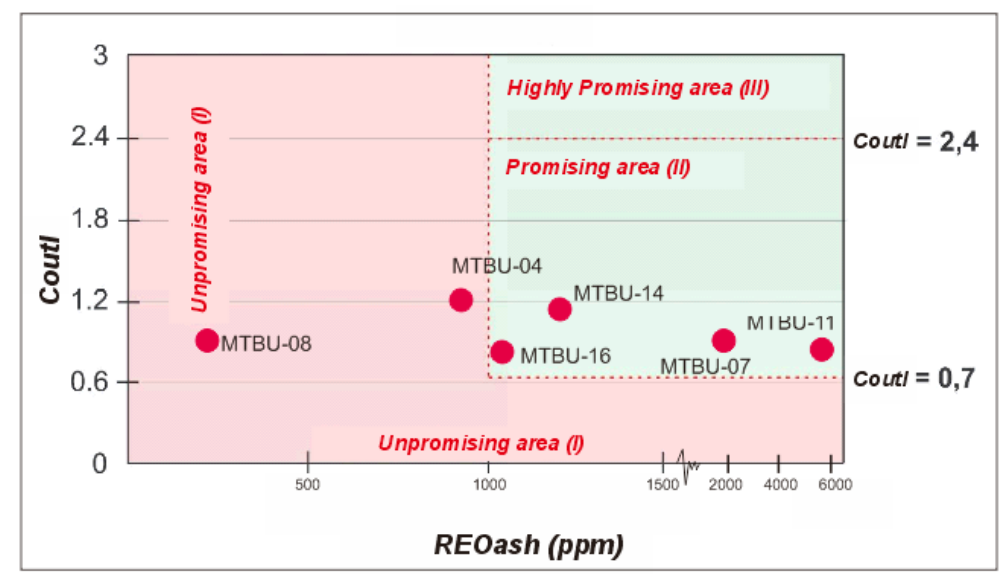

Gambar 13. Plot diagram $\mathrm{REO}_{\text {ash }}$ dan $\mathrm{C}_{\text {outl }}$ menurut Dai dan Finkleman (2018)

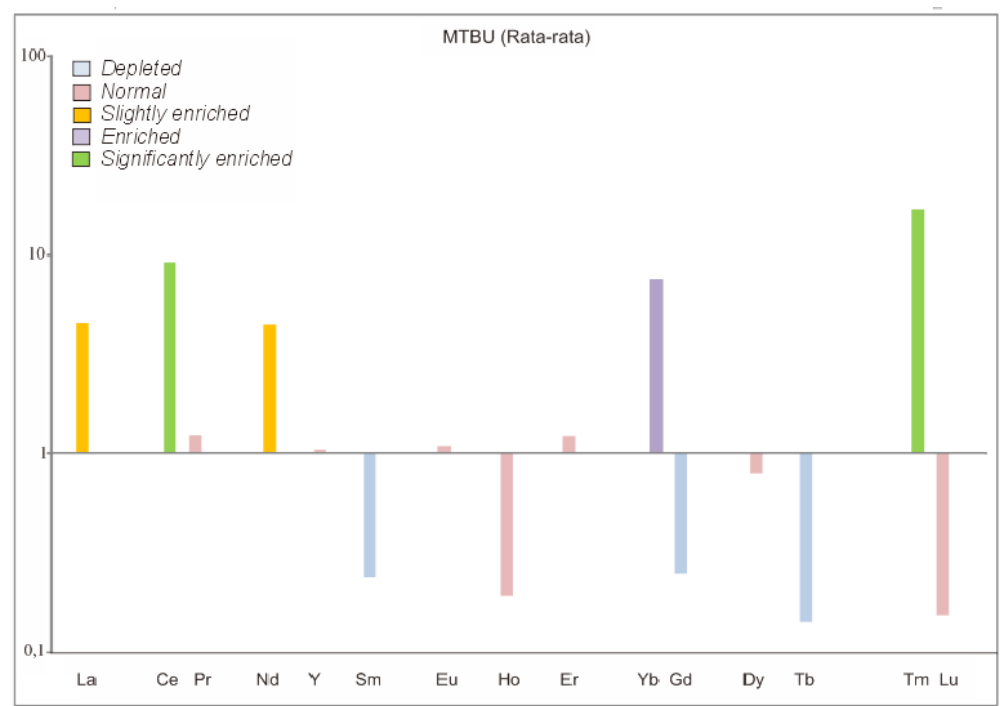

Gambar 14. Diagram concentration coefficient 


\section{Tipe Genetik Pengayaan Batubara}

\section{Tipe distribusi UTJ}

Tipe distribusi UTJ pada batubara menunjukkan hampir keseluruhan conto memiliki tipe $\mathrm{H}$ (Berat) $\left(\operatorname{La}_{N} / \mathrm{Lu}_{N}<1\right)$ (Gambar 15). Terdapat dua conto dengan tipe $\mathrm{H}$ dan $\mathrm{M}$, yakni conto MTBU-4 dan MTBU-6. Tipe $L\left(\operatorname{La}_{N} / L_{N}>1\right)$ dijumpai hanya pada conto MTBU.

Menurut Seredin dan Dai (2012), tipe distribusi UTJ yang menunjukkan tipe $L$ $\left(L_{N} / L u_{N}>1\right)$ memiliki tipe genetik tufaan, hal ini selaras pada conto MTBU-12 yang hadir sebagai parting pada batubara dengan litologi batupasir tufaan. Conto MTBU-12 memiliki konsentrasi total UTJ tertinggi pada keseluruhan conto nonbatubara. Keseluruhan conto kecuali conto MTBU-12 memiliki tipe $H$. Pengayaan dengan tipe ini dapat terjadi dengan proses pengayaan yang bervariasi. Secara dominan, pengayaan dapat terjadi karena sirkulasi air di sekitar cekungan batubara seperti air laut, air dari darat yang bersifat alkalin, dan vulcanogenic fluids (Seredin dan Dai, 2012). Pengayaan UTJ dengan nilai total konsentrasi UTJ tertinggi $(203,72$ ppm) terdapat pada lapisan batubara yang berada di atas lapisan parting.

Pengayaan tersebut relevan dengan pernyataan Seredin dan Dai (2012), dengan pengayaan batubara dapat berasosiasi dengan keterdapatan tonstein, khususnya pada tonstein tipe alkalin dan silisic. Keseluruhan conto clay band dengan litologi batulempung tufaan diplot pada diagram klasifikasi jenis tonstein oleh Dai dan Wang, (2011) berdasarkan perbandingan nilai $\mathrm{Al}_{2} \mathrm{O}_{3}$ dan $\mathrm{TiO}_{2}$. Menurut klasifikasi tersebut, dijumpai keseluruhan conto termasuk pada klasifikasi alkaline tonstein (Gambar 16).

\section{Anomali redox-sensitive dan redox non- sensitive}

Distribusi penyebaran unsur UTJ telah lazim digunakan untuk interpretasi genetik dan diferensiasi pada batuan beku dan kajian terhadap batuan sedimen, termasuk batubara. Anomali redox-sensitive dan redox non-sensitive akan menunjukkan interpretasi genetik tertentu pada unsur yang dianalisis. Perhitungan anomali redox-sensitive dan redox non-sensitive dilakukan pada keseluruhan conto bulk dan conto dengan konsentrasi tertinggi. Anomali diamati pada diagram distribusi konsentrasi UTJ yang telah dinormalisasi terhadap upper continental rrust pada tiaptiap conto. Diagram yang dihasilkan menunjukkan terdapat anomali $\mathrm{Ce}$ negatif pada hampir keseluruhan conto. Dai dan Xie, (2017) menyatakan anomali Ce negatif merupakan anomali yang umum terjadi karena proses pencucian pada parting batubara.

Anomali Eu menunjukkan anomali positif. Hal tersebut dapat menjadi indikasi terdapatnya pengaruh temperatur yang tinggi pada proses penggambutan batubara (Dai dan Xie, 2017). Pengaruh temperatur yang tinggi dapat disebabkan oleh terdapatnya intrusi magmatik di sekitar lokasi penelitian (Amijaya dan Littke, 2005). Selama pembentukan batubara tidak terdapat intrusi air laut yang berarti, dicirikan dengan anomali $Y$ negatif dan anomali $\mathrm{Gd}$ negatif. Hal tersebut juga didukung dengan kadar sulfur pada conto yang rendah. Anomali La menunjukkan positif dijumpai pada hampir keseluruhan conto yang mencirikan terdapat input material dengan kandungan $\mathrm{Ti}$ yang tinggi (Dai dan Xie 2017).

\section{Proses Pengayaan UTJ}

Proses pengayaan UTJ dianalisis melalui data yang berkaitan dengan komposisi batubara yakni hasil analisis geokimia, kadar abu dan kadar sulfur, kelimpahan maseral, dan kondisi geologis daerah penelitian. Berdasarkan hasil analisis geokimia diperoleh conto menunjukkan tipe distribusi tipe $\mathrm{L}$ dan $\mathrm{H}$. Tipe tersebut menunjukkan tipe pengayaan tufaan yang berkaitan dengan proses sirkulasi air. Hasil analisis anomali $Y$ dan $G d$ yang menunjukkan nilai negatif mengindikasikan pengayaan UTJ yang terjadi tidak 


\section{MAKALAH ILMIAH}

dipengaruhi oleh sirkulasi air laut, melainkan karena proses pencucian parting pada batubara yang dicirikan dengan anomali Ce negatif (Dai dan Xie, 2017).

Tidak terdapatnya pengaruh air laut selama proses pembentukan batubara didukung oleh konsentrasi sulfur yang rendah. Nilai total sulfur yang didapatkan berkisar 0,16 $2,98 \%$ dengan nilai rata-rata $0,92 \%$. Selain itu terdapat proses pengayaan yang berasal dari lapisan interseam berupa batupasir tufaan yang mengayakan UTJ pada batubara di atasnya bersama dengan sirkulasi air. Hasil analisis pola distribusi UTJ yang menunjukkan tipe $\mathrm{L}$ menunjukkan tipe genetik tufaan yang terkayakan pada fase penggambutan pada proses pembentukan batubara (Gambar 17).

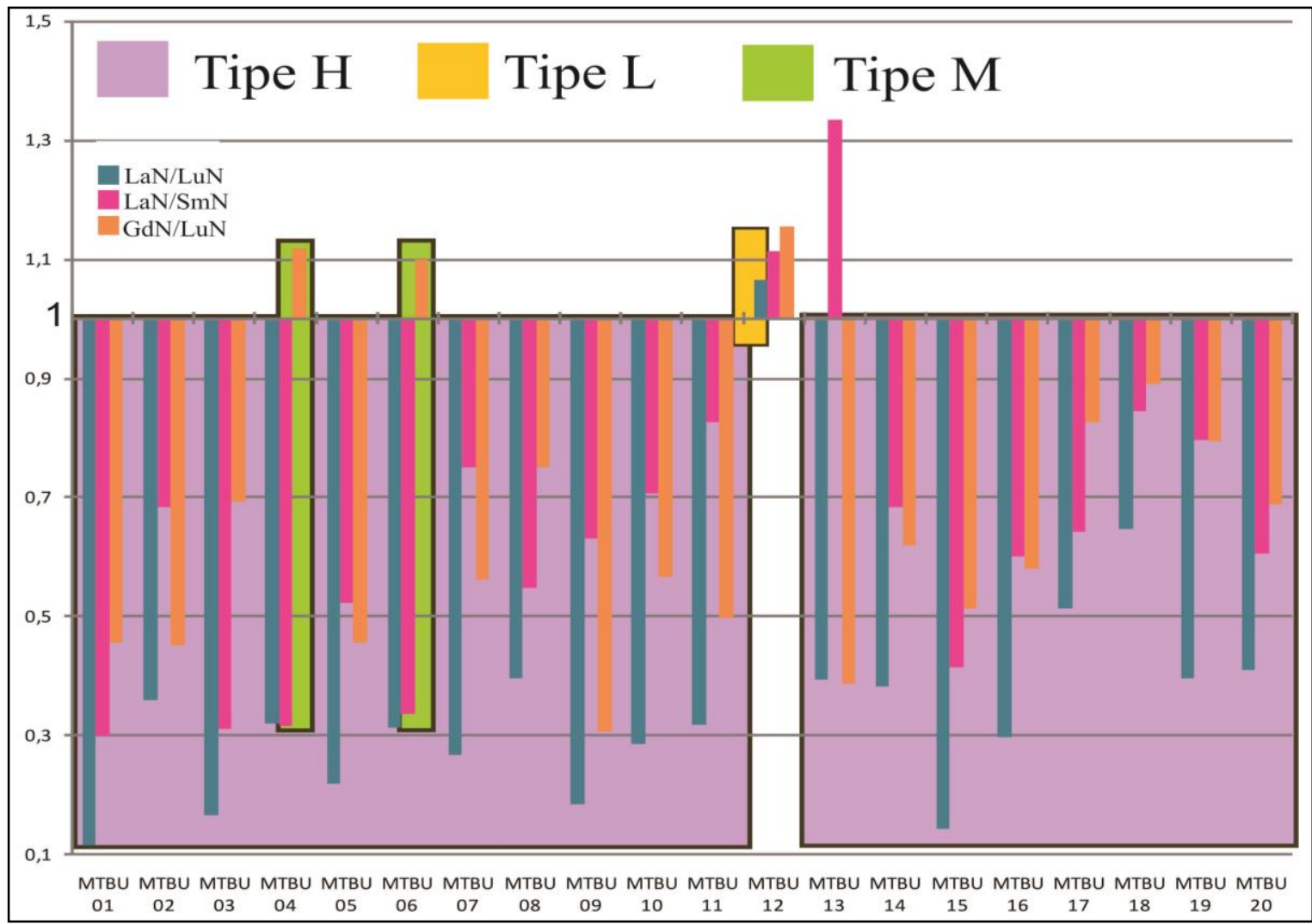

Gambar 15. Tipe distribusi UTJ
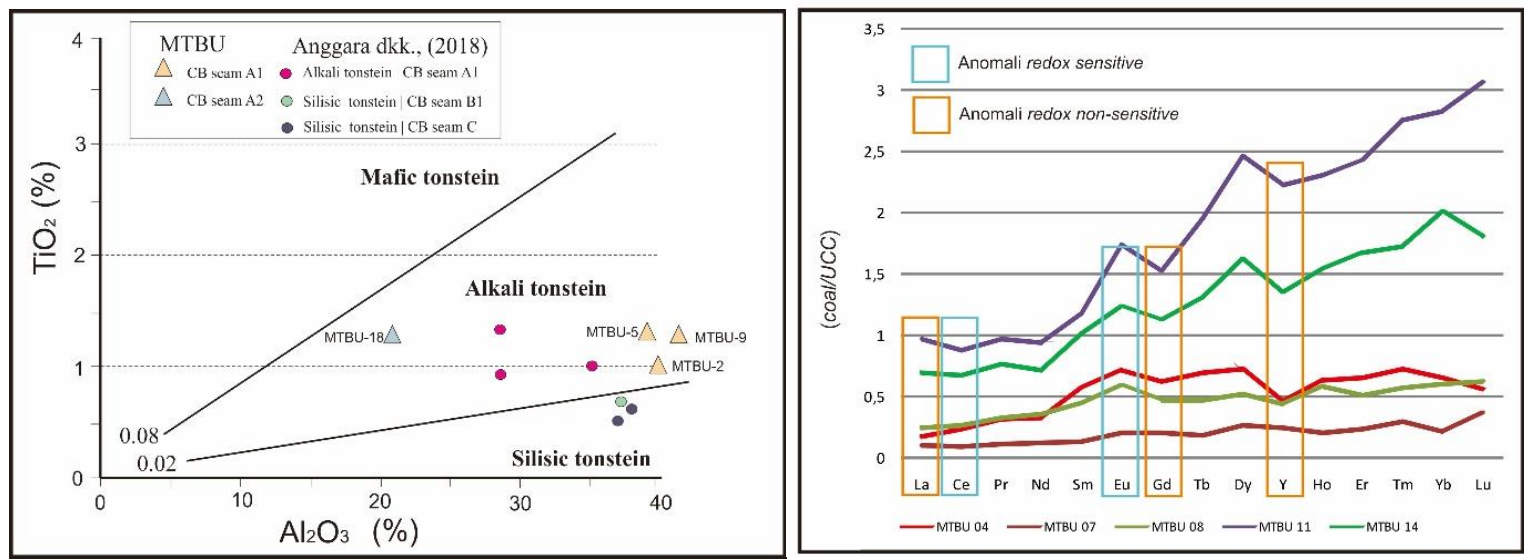

Gambar 16. Plot klasifikasi tonstein berdasarkan Dai (2011), diagram anomali redox-sensitive dan redox-non sensitive 


\section{MAKALAH ILMIAH}

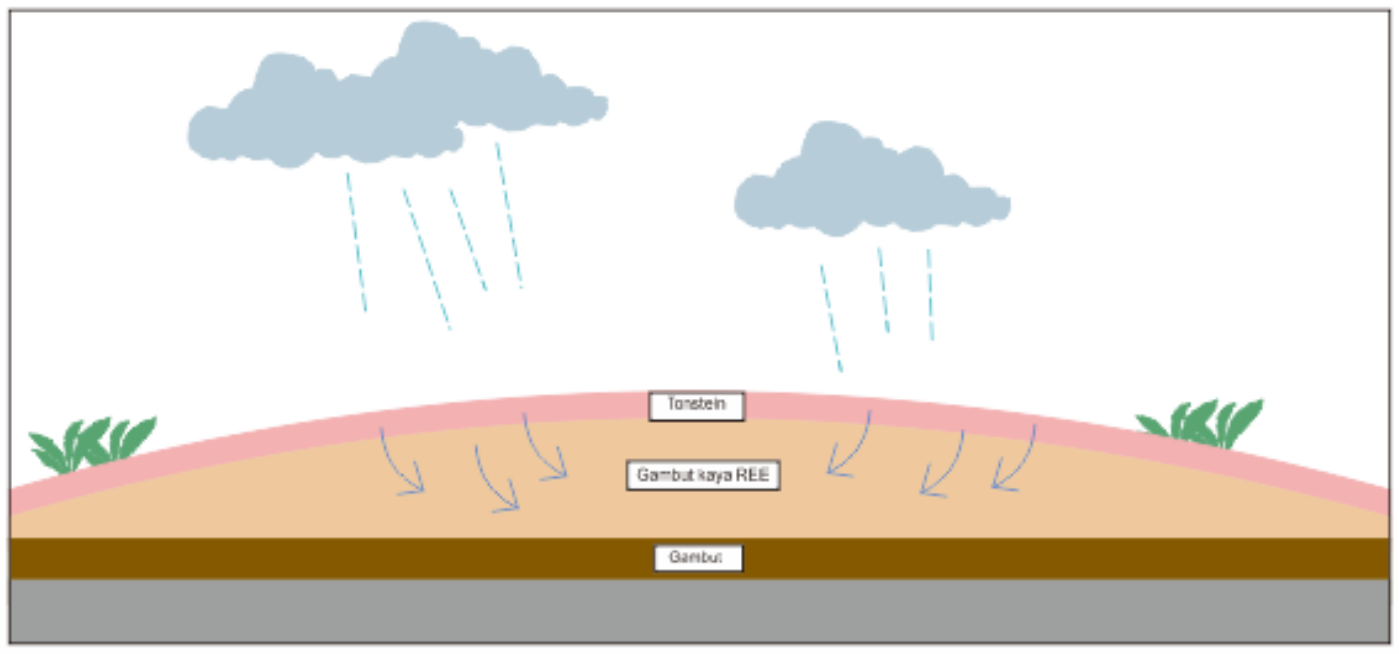

Gambar 17. Model proses pengayaan UTJ

Menurut Seredin dan Dai (2012) tipe genetik tufaan mencirikan pengayaan UTJ terjadi pada peat bog stage pembentukan batubara. Kelimpahan maseral pada keseluruhan perlapisan batubara menunjukkan pada bagian bawah (Lapisan Batubara A2) didominasi oleh subgrup maseral telohumunit dan maseral liptinit, sedangkan pada bagian atas (Lapisan Batubara A1) didominasi oleh subgrup maseral telohuminit dan inertinit. Subgrup maseral telohumionit hadir berasosiasi dengan subgrup detrohuminit dengan persentase yang berimbang. Hal ini dapat mengindikasikan selama proses pengendapan batubara terdapat mekanisme fluktuasi permukaan air. Keterdapatan grup maseral liptinit dengan persentase yang tinggi mengindikasikan pembentukan batubara terjadi pada kondisi sub-aquatic dicirikan dengan kehadiran maseral liptodetrinit yang melimpah (2,413,6\%) (Teichmuller, 1989 dalam Amijaya dan Littke, 2005). Kondisi sub-aquatic tersebut mengindikasikan input air intensif yang bersirkulasi membawa hasil pencucian parting (tonstein) yang menyebabkan pengayaan UTJ pada gambut, sehingga ketika terjadi proses pembatubaraan diperoleh batubara yang memiliki pengayaan UTJ. Pengayaan UTJ akan terkonsentrasi pada batubara di sekitar perlapisan parting, karena konsentrasi UTJ akan semakin berkurang jika semakin menjauhi sumber pengayaan UTJ.

\section{KESIMPULAN}

Batubara pada Lapangan Muara Tiga Besar Utara, Tanjung Enim, Cekungan Sumatera Selatan mengalami pengayaan UTJ tipe UTJ Berat dengan total konsentrasi tertinggi mencapai 203,72 ppm. Tipe genetik pengayaan UTJ tergolong pada tipe tufaan dan termasuk pada tipe distribusi UTJ tipe $\mathrm{H}$ yang berkaitan dengan sirkulasi air. Pengayaan UTJ merupakan hasil pencucian alkaline tonstein pada fase penggambutan batubara.

\section{DAFTAR PUSTAKA}

Amijaya, H., and Littke, R., 2005, Microfacies and depositional environment of Tertiary Tanjung Enim low rank coal, South Sumatra Basin, Indonesia. Int. J. Coal Geol, 61. p. 7-221.

Anggara, F., Amijaya, D.H., Harijoko, A., Tambaria, N.T., Sahri, A.A., and Asa, Z.A.N., 2018, Rare earth element and yttrium content of coal in the Banko coalfield, South Sumatra Basin, Indonesia: Contribution from tonstein layers. Int. J. Coal Geol, 196. p. 159172.

Barber, A.J., Crow, M.J., and Milsom, J., 2005, Sumatra: geology, resources and tectonic evolution: London, The Geological Society, $290 p$. 
Bohor, B.F., and Triplehorn, D., 1993, Tonstein: altered volcanic ash layers in Coal Bearing Sequences: Geological Society of America Spec, 285, p. 44.

Castor, S.B., Hedrick, J.B., 2006, Rare Earth Elements. Society for Mining, Metallurgy, and Exploration, vol. 7 p. 769-792.

Dai, S., Graham IT., and Ward C.R., 2017. A review of anomalous rare earth elements and yttrium in coal. Int. J. Coal Geol, 159. p. 82-95.

Dai, S., Ren, D., Chou, C.L., Finkelman, R.B., Seredin, V.V., Zhou, Y., 2011, Geochemistry of trace elements in Chinese coals: $A$ review of abundances, genetic types, impact on human health, and industrial utilization. Int. J. Coal Geol, 94. p. 3-21.

Dai, S., Wang, X., Zhou, Y., Hower, J.C., Li, D., Chen, W., Zhu, X., and Zou, J., 2011, Chemical and mineralogical compositions of silicic, mafic, and alkali tonsteins in the late Permian coals from the Songzao Coalfield, Chongqing, Southwest China. Chemical Geology, 282. p. 29-44.

Dai, S., Weiguo, Z., Seredin, V.V., Ward, C.R., Hower, J.C., Song, W., Wang, X., Li, X., Zhao, L., Kang, H., Zheng, L., Wang, P., and Zhou, D., 2013, Factors controlling geochemical and mineralogical compositions of coals preserved within marine carbonate sUCCesions: a case study from the Heshan Coalfield, Southern China: Int. J. Coal Geol. 109-110, 77-100 p.

Dai, S., Xie, P., Jia, S., Ward, C.R., Hower, J.C., Yan, X., and French, D. 2017, Enrichment of $U-R e-V-C r-S e$ and rare earth elements in the Late Permian coals of the Moxinpo Coalfield, Chongqing, China: Genetic Implications from geochemical and mineralogical data: Int. J. Coal Geol,80.p. 1-17. de Coster, G.L., 1974, The geology of Central and South Sumatra Basins. Proceedings Indonesian Petroleum Association 3rd Annual Convention. Jakarta. p. 77-110.

Humphries, M., 2011, Rare Earth Elements: The Global Supply Chain, Diane Publishing. $18 p$.

Ketris, M.P., Yudovich, Ya.E., 2009, Estimations of Clarkes for Carbonaceous biolithes: World averages for trace element contents in black shales and coals. Int. J. Coal Geol, 78.p. 135-148.

Pickel, W., Kus, J., Flores, D., Kalaistzidis, S., Christanis, K., Cardott, B.J., MiszKennan, M., Rodrigues, S., Hentschel, A., Hamor-Vido, M., Crosdale, P., Wagner, N., ICCP, 2017, Classification of liptinite. Int. J. Coal Geo,. 169.p. 4061.

Pujobroto, A., 1997, Organic petrology and geochemistry of Bukit Asam coal, South Sumatra, Indonesia: Unpublished Ph.D. thesis, University of Wollongong, Australia, $420 p$.

Seredin, V. V., 1996. Rare Earth ElementBearing Coals from the Russian Far East Deposits. Int. J. Coal Geol, 30.p. 101-129.

Seredin, V.V., Dai, S., 2012, Coal deposits as potential alternative sources for lanthanides and yttrium. Int. J. Coal Geol, 94.p. 67-93.

Shell Mijnbouw, N.V., 1978, Geological study of the Bukit Asam coal mines: Jakarta, 7-17 p. (unpublished).

Sykorova, I., Pickel, W., Christanis, K., Wolf, M., Taylor, G.H., Flores, D., 2004, Classification of huminite-ICCP System 1994. Int. J. Coal Geol, 62. p.85-106.

Susilawati, R., and Collin, R.W, Metamorphism of mineral matter in coal from the Bukit Asam deposit, south Sumatera, Indonesia. Int. J. Coal Geol, 68.p. 171-195.

Triplehorn, D., 1990, Applications of tonstein to coal geology: some examples from western United States. Int. J. Coal. Geol, 16.p. 157-160.

\begin{tabular}{|ll|}
\hline Diterima & $: 25$ Oktober 2019 \\
Direvisi & $: 14$ November 2019 \\
Disetujui & $: 30$ November 2019 \\
\hline
\end{tabular}

